PAEDAGOGIA CHRISTIANA

2/26(2010) - ISSN 1505-6872

Leonard Fic*

Włocławek-Warszawa

\title{
Dialog międzyreligijny
}

Dialog międzyreligijny nie jest rzeczywistością nową. Wyznawcy różnych religii spotykali się z sobą zawsze i z pewnością wymieniali wówczas swoje poglądy na temat wyznawanej przez siebie wiary. Chrześcijaństwo również od początku swojego istnienia prowadziło dialog z judaizmem i politeistycznymi religiami basenu Morza Śródziemnego. Historia misji odnotowuje imiona i nazwiska wielkich pionierów dialogu międzyreligijnego: Mateo Ricci'ego (1552-1610), nazywanego „zachodnim konfucjanistą", czy Roberto de Nobili (1577-1656), uchodzącego w Indiach za chrześcijańskiego „sannjasina” Zachodu'. Zatem dialog międzyreligijny na długo przed Soborem Watykańskim II był już rzeczywistością trwałą w wielu rejonach świata, gdzie Kościół żył na co dzień w bezpośredniej bliskości z wyznawcami innych religii. Vaticanum II nadało mu jednak nowy poryw i uczyniło go jednym z najważniejszych punktów odnowy Kościoła. Soborowe „aggiornamento” zakładało „rzeczywistą otwartość serca i umysłu wobec różnych religii świata. Spotkanie w Asyżu w 1986 r. potwierdziło tę otwartość...”2.

Niniejsze opracowanie przedstawia w zarysie rzeczywistość dialogu międzyreligijnego w świetle dokumentów Urzędu Nauczycielskiego Kościoła: Ecclesiam suam (1), Soboru Watykańskiego II (2) i posoborowych (3). Omawia także podstawowe wymagania (4) i formy tej rzeczywistości (5).

* Ks. dr hab. Leonard Fic jest wykładowcą na Wydziale Teologicznym Uniwersytetu Kardynała Stefana Wyszyńskiego w Warszawie.

1 Zob. J. Urban, Dialog międzyreligijny w posoborowych dokumentach Kościoła, Opole 1999, s. 14.

${ }^{2}$ G. Martelet, Zapomniany Sobór, Kraków 1997, s. 90. 


\section{Encyklika dialogu}

Słowo „dialog” weszło stosunkowo późno do słownictwa oficjalnych dokumentów Kościoła ${ }^{3}$. Pojawiło się ono po raz pierwszy w programowej encyklice papieża Pawła VI, Ecclesiam suam, opublikowanej 6 sierpnia 1964 roku, między II a III sesją Soboru. Był to moment, kiedy jeszcze wiele innych ważnych dokumentów soborowych było w fazie opracowywania. Nie ulega więc watpliwości, że Ecclesiam suam, nazywana ,encykliką dialogu”, wytyczyła zasadniczy kierunek prac soborowych, jakim był dialog (colloquium) Kościoła „ze światem współczesnym” (ES 14). „Kościół - czytamy w encyklice - powinien nawiązywać dialog ze społecznością ludzką, w której żyje; dlatego powinien stać się Kościołem słowa, orędzia i rozmowy" (ES 65).

Źródłem i odzwierciedleniem dialogu jest wewnętrzne życie Boga w Trójcy Świętej. Jest ono odwiecznym dialogiem Słowa (Logos) z Bogiem Ojcem w Duchu Świętym. W Jezusie Chrystusie dialog ten znajduje swój cielesny wyraz (Kol 2,9) i kontynuację. Jezus podczas swojej publicznej działalności prowadzi dialog z apostołami, uczniami, faryzeuszami, Nikodemem (J 18, 33-37), Samarytanką (J 4, 1-30), a nawet z Piłatem (J 18,33-37). Nie podejmuje go jednak z Herodem Agrypa, ponieważ nie znajduje w nim dobrej woli (Łk 23, 8-12). Dialog Jezusa podejmują następnie Apostołowie z wszystkimi ludźmi, nie zważając na narodowość, pochodzenie czy przekonania $(K o l 3,11)$, i nie stosując żadnej formy przymusu ${ }^{4}$. Jest to dialog zbawienia. Został on zapoczątkowany przez Boga. Bóg bowiem ,pierwszy nas umiłował” (1 J 4, 10; ES 72) i ,Syna swego Jednorodzonego dał, aby każdy, kto w Niego wierzy, nie zginął, ale miał życie wieczne" (J 3, 16; ES 73). Stąd chrześcijanie, wzorem samego Boga, powodowani szczerą miłością, winni jako pierwsi szukać dialogu ze wszystkimi ludźmi, nie czekając „,na propozycje z ich strony" (ES 93).

Po przedstawieniu istotnych właściwości, metod i technik dialogu (ES 81-86) papież Paweł VI nakreślił w Ecclesiam suam cztery jego podstawowe kręgi, „pośrodku których umieściła Kościół Boża ręka” (ES 96). Pierwszy, „nie dający się ogarnąć ludzkim okiem, kragg, którego krańce nikną w niezmierzonej dali: to świat, cała ludzkość" (ES 97). W jego obrębie jest wielu niewierzących i przeczących istnieniu Boga, czyli ateistów

3 S. Gądecki, O naturze, warunkach, rodzajach i celu dialogu międzyreligijnego, w: W. Chrostowski (red.), Ja jestem Józef brat wasz. Księga pamiatkowa ku czci Arcybiskupa Henryka Józefa Muszyńskiego Metropolity Gnieźnieńskiego w 65 rocznicę urodzin, Warszawa 1998, s. 131.

4 Tamże, s. 131. 
(ES 99-105). Krag drugi stanowią „,wierzący w Boga” (ES 113), trzeci „bracia odłączeni” (ES 113), czwarty i ostatni, zwany „kręgiem domowym”, obejmuje „dzieci mieszkające w domu Bożym”, tj. „w jednym, świętym, katolickim i apostolskim Kościele, którego «matką i głową» jest Kościół Rzymski” (ES 113). Dialog międzyreligijny w ścisłym tego słowa znaczeniu dotyczy kręgu drugiego. Należą do niego ci, którzy, tak jak chrześcijanie, wierzą w ,jedynego i najwyższego Boga”, a więc w pierwszym rzędzie przedstawiciele narodu żydowskiego, następnie muzułmanie, nazwani w encyklice mahometanami, oraz wyznawcy „,wielkich religii afrykańskich i azjatyckich” (ES 107). „Obowiązek szczerości - podkreślił jednak papież - nakazuje nam oświadczyć, zgodnie z naszą wiara, że prawdziwa religia jest jedna i że jest nią religia chrześcijańska. Mamy także nadzieję, że kiedyś uznają to wszyscy, którzy Boga szukają i oddają Mu cześć" (ES 107). Zwracając „uwagę na duchowe i moralne wartości znajdujące się w różnych religiach niechrześcijańskich", Paweł VI wyraził gotowość do współpracy z nimi „w dziedzinie wolności religijnej, braterstwa między ludźmi, wykształcenia, nauki, działalności charytatywnej czy ustroju społecznego" (ES 108). Na tym polu, według papieża, otwierają się wielkie możliwości do dialogu z tymi religiami (ES 108).

\section{Dialog międzyreligijny w dokumentach Soboru Watykańskiego II}

Teologiczne przesłanie o możliwościach, płaszczyznach i warunkach dialogu Kościoła katolickiego z religiami pozachrześcijańskimi, zawarte w encyklice Ecclesiam suam, znalazło swoje wyraźne odbicie w dokumentach Soboru Watykańskiego II, przede wszystkim w ogłoszonej 28 października 1965 r. Deklaracji o stosunku Kościoła do religii niechrześcijańskich Nostra aetate. Dokument ten miał początkowo przedstawić stosunek Kościoła katolickiego do wyznawców judaizmu, którzy w okresie niemieckiego narodowego socjalizmu przeżyli dramat holokaustu (szoah) (1933-45) . Zamierzano nie tylko potępić antysemityzm, lecz także przypomnieć o starotestamentowych korzeniach chrześcijaństwa. Jednak ówczesna sytuacja ekonomiczno-polityczna, a zwłaszcza konflikt w Zatoce Perskiej między wyznawcami religii mojżeszowej a muzułmanami, przynaglił Ojców Soboru do ustosunkowania się również wobec wyznawców islamu. Ostatecznie

${ }^{5}$ H. Muszyński, Holokaust, w: J. Walkusz (red.), Encyklopedia Katolicka, t. VI, Lublin 1993, kol. 1154-1155. 
treść Deklaracji objęła religijne tradycje Azji, Afryki i Ameryki Łacińskiej6. Było to niewątpliwie zasługą Pawła VI, który jako pierwszy w historii papież udał się z misją apostolską daleko poza granice Rzymu, odwiedzając Ziemię Świętą (1964), Indie (1964), Afrykę (1969) oraz kraje Azji, Australii i Oceanii (1970). Szczególne znaczenie miała obecność papieża na Kongresie Eucharystycznym w Bombaju w Indiach (grudzień 1964). Z pewnością zadecydowała ona o ostatecznym kształcie soborowej deklaracji Nostra aetate. Głęboka religijność narodu indyjskiego wywarła na papieżu wielkie wrażenie. $\mathrm{Na}$ zorganizowanym wówczas spotkaniu z przedstawicielami religii pozachrześcijańskich Paweł VI ,wyrażał się z podziwem o naturalnej dobroci, cierpliwości i pokorze synów tego kraju, podkreślał religijne usposobienie i przywiązanie do życia rodzinnego, jakie cechuje Indie i wszystkie ludy Azji"”.

Nostra aetate jest pierwszym w historii świadectwem pozytywnej oceny religii pozachrześcijańskich przez Magisterium Kościoła ${ }^{8}$. Słowa: „Kościół katolicki nic nie odrzuca $\mathrm{z}$ tego, co w religiach owych prawdziwe jest i święte” oraz, że ,ze szczerym szacunkiem odnosi się do owych sposobów działania i życia, do owych nakazów i doktryn, które... odbijają promień owej Prawdy, która oświeca wszystkich ludzi” (DRN 2), wyrażają nową postawę Kościoła wobec religii pozachrześcijańskich. Ta nowość obecna jest także w treści innych dokumentów soborowych. Polega ona przede wszystkim na tym, że Kościół rozpoznaje w religiach niechrześcijańskich elementy „prawdy i łaski” (DM 9). Mają one swoje źródło w ,jakby ukrytej obecności Boga" (DM 9). Ujawniają się one nie tylko w życiu religijnym pojedynczych wyznawców tych religii, lecz także we „własnych obrządkach i kulturach narodów” (KK 17). Postrzega się je jako „drzemiące w nich zarodki Słowa” (DM 11) oraz „promień owej Prawdy, która oświeca wszystkich ludzi” (DRN 2). Ponadto rosła na Soborze coraz bardziej świadomość oddziaływania Ducha Świętego, który jest także Duchem Chrystusa napełniającym cały „okrąg ziemi” (KDK 11). Dekret o działalności misyjnej Kościoła Ad gentes i Konstytucja duszpasterska o Kościele w świecie współczesnym Gaudium et spes czynią wyraźne odniesienia do tej uniwersalnej obecności Ducha Świętego w czasie i przestrzeni: „Bez wątpienia Duch Święty działał już na świecie, nim jeszcze Chrystus został uwielbiony” (DM 4). To działanie Ducha Świętego ujawnia się także w świecie współczesnym, w szlachetnych

${ }^{6}$ B. Dembowski, Wprowadzenie do Deklaracji o stosunku Kościoła do religii niechrześcijańskich, w: Sobór Watykański II. Konstytucje. Dekrety. Deklaracje, Poznań 2002, s. 328.

7 E. Bulanda, Misyjny dialog Kościoła dzisiejszego z religiami niechrześcijańskimi, w: H. Bogacki, S. Moysa (red.), Kościót w świetle Soboru, Poznań 1968, s. 409.

${ }^{8}$ Zob. C. Geffré, Dialog religii, w: F. Lenoir, Y. Tardan-Masquelier (red.), Encyklopedia religii świata, Warszawa 2002, s. 2397. 
pragnieniach tych mężczyzn i kobiet, którzy pragną lepszej jakości swojego życia i bardziej godnego człowieka porządku społecznego (KDK 38-39). Sprawia ono w sercu człowieka to, że nie pozostanie on nigdy ,zupełnie obojętny na problemy religijne" i nie przestanie szukać odpowiedzi na pytanie o „sens” swojego „życia, działalności i śmierci” (KDK 41, 10). Człowiek odkupiony przez Chrystusa stał się „nowym stworzeniem” w Duchu Świętym. Stąd też „ostateczne powołanie człowieka jest rzeczywiście jedno, mianowicie boskie”, a „Duch Święty wszystkim ofiarowuje możliwość dojścia w sposób Bogu wiadomy do uczestnictwa w tej paschalnej tajemnicy" (KDK 22). Ożywiona i zgromadzona w Duchu Chrystusa Zmartwychwstałego ludzkość ,pielgrzymuje ku wypełnieniu się historii ludzkiej” (KDK 45) z żywą nadzieją, która jest darem Ducha Świętego (KDK 93). Wskazując na ten głęboki fundament dialogu międzyreligijnego, Kościół „wzywa synów swoich, aby z roztropnością i miłością przez rozmowy i współpracę z wyznawcami innych religii, dając świadectwo wiary i życia chrześcijańskiego, uznawali, chronili i wspierali owe dobra duchowe i moralne, a także wartości społeczno-kulturalne, które u tamtych się znajdują" (DRN 2). Podobne apele powracają w innych dokumentach soborowych. W Ad gentes czytamy, że uczniowie Chrystusa przepełnieni głęboko Jego duchem niech tak ,poznają ludzi, wśród których żyją i niech tak z nimi przestają, aby się oni przez szczery i cierpliwy dialog dowiedzieli, jakimi bogactwami szczodrobliwy Bóg obdarzył narody; równocześnie zaś niech usiłują owe bogactwa rozjaśniać światłem Ewangelii..." (DM 11). Konstytucja duszpasterska o Kościele w świecie współczesnym Gaudium et spes, określana także wielką kartą dialogu, wyraża pragnienie, ,,aby otwarta wymiana poglądów skłoniła wszystkich nas do przyjęcia i ochoczego wykonania natchnień Ducha Świętego" (KDK 92). Te wzniosłe słowa dokumentów soborowych nie określają jednak miejsca, jakie zajmuje dialog w całej misji Kościoła. Stopniowe wyjaśniane tego aspektu podejmie dopiero nauczanie posoborowe, które określi dialog międzyreligijny integralną częścią ewangelizacyjnej misji Kościoła.

\section{Dialog międzyreligijny w nauczaniu posoborowym}

Szczególnie ważnym wydarzeniem dla rozwoju dzieła dialogu międzyreligijnego było powołanie do życia przez papieża Pawła VI, listem apostolskim Progrediente concilio z 19 maja 1964 r., a więc jeszcze w klimacie obrad soborowych, Sekretariatu dla Niechrześcijan. Od 1988 r. nosi on nazwę

9 Zob. AAS 56 (1964), s. 560. 
Papieskiej Rady do Spraw Dialogu Międzyreligijnego. Zasadniczym celem tej instytucji jest wyłącznie służba dziełu dialogu Kościoła katolickiego z religiami niechrześcijańskimi ${ }^{10}$. Od maja 1966 r. dykasteria ta wydaje specjalne czasopismo noszące na początku tytuł Bulletyn, a obecnie Pro dialogo. Prezentuje ono bogatą dokumentację wszelkiej aktywności papieża, różnych urzędów Stolicy Apostolskiej, episkopatów świata, teologów i ekspertów na polu dialogu międzyreligijnego.

Ze względu na skromne łamy tego artykułu ograniczamy się tutaj jedynie do analizy dwóch dokumentów tej dykasterii, tj.: Postawa Kościoła wobec wyznawców innych religii. Refleksje $i$ wskazania dotyczqce dialogu i misji ${ }^{11}$ i Dialog i przepowiadanie ${ }^{12}$, zredagowanego we współpracy z Kongregacją Ewangelizacji Ludów.

Pierwszym z tych dokumentów - Postawa Kościoła wobec wyznawców innych religii - Sekretariat dla Niechrześcijan, dokonując oceny doświadczeń na polu dialogu, jakie miały miejsce w Kościele w ciagu dwudziestu lat od ogłoszenia encykliki Ecclesiam suam, podejmuje refleksje nad samą istotą posłannictwa Kościoła, teologicznymi podstawami dialogu, jego formami i relacją między dialogiem a posłannictwem. Kościół czuje się zobowiązany do dialogu przede wszystkim ze względu na swoją wiarę w Boga w Trójcy Świętej Jedynego. „W tajemnicy trynitarnej, dzięki objawieniu, dostrzegamy życie w komunii i we wzajemnej wymianie"13. Uprzedzająca miłość Boga Ojca „nie jest ograniczona ani czasem, ani przestrzenią”" ${ }^{14}$. Poprzez Wcielenie Syn Boży zjednoczył się z każdym człowiekiem. „W Nim objawia się Tajemnica Boga a zarazem człowieka” ${ }^{15}$. Duch Święty zaś „«przekracza w swym działaniu widzialny obręb Mistycznego ciała»"16, czyli Kościoła, który jest „zarodkiem i początkiem Królestwa Bożego, ostatecznego celu wszystkich ludzi" "'. Kościół, przygotowując jego nadejście, winien z uwagą i szacunkiem odnosić się do faktu, iż, ,w niechrześcijańskich tradycjach religijnych istnieją elementy «dobre i prawdziwe» (Optatam totius, 16), «cenne

${ }^{10}$ Zob. J. Urban, dz. cyt., s. 142 n.

11 Postawa Kościoła wobec wyznawców innych religii. Sekretariat dla Niechrześcijan, 10 czerwca 1984, w: W. Chrostowski, R. Rubinkiewicz (red.) Żydzi i judaizm w dokumentach Kościoła i nauczaniu Jana Pawła II (1965-1989), Warszawa 1990, s. 44-59; przedruk w: E. Sakowicz (red.), Islam w dokumentach Kościoła i nauczaniu Jana Pawła II (1965-1996), Warszawa 1997, s. 30-44.

12 Dialog i przepowiadanie, „Nurt SVD” 27 (1993), nr 3, s. 75-106.

13 Postawa, 21-22.

14 Tamże, 22.

15 Tamże, 23.

16 Tamże, 24.

17 Tamże, 25. 
elementy religijne i ludzkie» (Gaudium et spes, 92), nasiona kontemplacji (Ad gentes, 18), elementy «prawdy i łaski» (Ad gentes, 9), «zarodki i słowa» (Ad gentes, 11,15), «zawierają promień owej prawdy, która oświeca wszystkich ludzi» (Nostra aetate, 2)"18. Są to wartości, które skutecznie skłaniają Kościół do dialogu z tymi tradycjami religijnymi.

Dokument Sekretariatu dla Niechrześcijan rozpatruje rzeczywistość dialogu między religiami w kontekście relacji między działalnością misyjną a nawróceniem oraz w odniesieniu do Królestwa Bożego. W tej ostatniej perspektywie staje się on ,źródłem nadziei i prowadzi do zjednoczenia we wzajemnej przemianie”" ${ }^{\prime}$. Jest on dostosowany do czasu „Bożej cierpliwości, w którym pracuje Kościół i każda chrześcijańska wspólnota, gdyż nikt nie może zobowiązać Boga, by działał szybciej niż On sam postanowił”20. Mówiąc zaś o celu misyjnej działalności Kościoła, którym jest „przepowiadanie Ewangelii i zakładanie Kościoła wśród ludów i grup, gdzie Kościół nie zapuścił jeszcze korzeni" (Ad gentes, 6) ${ }^{21}$, dokument wyjaśnia, że Kościół pełni to posłannictwo przez obecność i żywe świadectwo chrześcijańskiego życia, przez zaangażowanie się w służbie człowieka i na rzecz postępu społecznego, przez walkę z nędzą i ze strukturami, które do niej prowadza, przez życie liturgiczne, modlitwę, kontemplację, dialog, przepowiadanie i katechezę. Wszystkie te elementy tworzą jednolita, aczkolwiek złożoną i pełną powiązań rzeczywistość posłannictwa Kościoła ${ }^{22}$.

Drugi ze wspomnianych dokumentów, opracowany już przez Papieską Radę do Spraw Dialogu Międzyreligijnego ${ }^{23}$ i Kongregację Ewangelizacji Ludów, Dialog i przepowiadanie, ukazał się 19 maja 1991 r. Było to wkrótce po ogłoszeniu przez Jana Pawła II, dnia 7 grudnia 1990 r., encykliki Redemptoris missio z okazji 25 rocznicy soborowego dekretu misyjnego ${ }^{24}$. Obydwa te dokumenty są bliskie sobie zarówno pod względem treści, jak i ducha, który je wypełnia. Należy zatem czytać i interpretować ich treści „paralelnie" ${ }^{25}$.

\footnotetext{
18 Tamże, 26.

19 Tamże, 43.

20 Tamże, 44.

21 Tamże, 44.

22 Tamże, 11-13.
}

${ }^{23}$ Jan Paweł II mocą konstytucji apostolskiej Pastor bonus z dnia 28 czerwca $1988 \mathrm{r}$. wprowadził pojęcie dialogu do nazwy rad papieskich, zajmujących się wyznawcami innych religii i niewierzącymi. Zob. AAS 80 (1988), s. 841-912. Por. J. Urban, dz. cyt., s. 142.

${ }^{24}$ Redemptoris missio, „L'Osservatore Romano” XII (1991), nr 1, s. 4-37.

${ }_{25}$ Zob. E. Sakowicz, Dialog Kościoła z islamem wedlug dokumentów soborowych i posoborowych (1963-1999), Warszawa 2000, s. 121. 
Redemptoris missio naucza, iż „Dialog międzyreligijny należy do misji ewangelizacyjnej Kościoła. [....] dialog nie przeciwstawia się misji ad gentes, ale przeciwnie, jest z nią w szczególny sposób powiązany i stanowi jej wyraz" (RM 55). Misja wyraża się na różne sposoby, także na drodze dialogu. Dialog nie zwalnia od ewangelizacji. Źródłem bowiem zbawienia jest Chrystus (RM 55), a nie człowiek, chociażby był on bardzo religijny. „W świetle ekonomii zbawienia - czytamy w Redemptoris missio - Kościół nie widzi sprzeczności między głoszeniem Chrystusa a dialogiem międzyreligijnym...” (RM 55). Chodzi o to, aby „oba te elementy zachowywały swą ścisłą więź i zarazem swą odrębność...” (RM 55). Wzajemne relacje obu tych elementów wymagały jeszcze doprecyzowania.

Teologiczne podstawy misji ewangelizacyjnej Kościoła czerpie encyklika z osoby Jezusa Chrystusa, „który jest «drogą, prawdą i życiem»”, z Jego „wezwania do wiary i chrztu, których Bóg pragnie dla wszystkich ludów”, oraz z konieczności Kościoła, który ,jest zwyczajną drogą zbawienia i tylko on posiada pełnię zbawczych środków" (RM 55). Dialog międzyreligijny, czytamy w encyklice, ,zmierza ku owemu oczyszczeniu i nawróceniu wewnętrznemu, które - gdy dokonuje się w posłuszeństwie Duchowi Święte$\mathrm{mu}$ - przyjmuje duchowe owoce" (RM 56). Jest on ,jedną z dróg Królestwa i niewątpliwie wyda owoce, chociaż czasy i chwile Ojciec ustalił swoją władzą (por. Dz 1, 7)" (RM 57).

Celem dialogu międzyreligijnego, jak mówi dokument Dialog i przepowiadanie, nie jest jedynie osiagnięcie wzajemnego zrozumienia i nawiązanie relacji przyjaźni z inaczej wierzącymi.

Dochodzi on do poziomu dużo głębszego, do poziomu samego ducha. Przez dialog chrześcijanie i niechrześcijanie są zaproszeni, aby pogłębić wymiary religijne ich zaangażowania i odpowiedzieć z rosnącą uczciwością na osobiste wezwanie Boga i na darmowy dar, w którym daje się On sam, dar, który przechodzi zawsze, jak mówi nasza wiara, przez pośrednictwo Jezusa Chrystusa i dzieło jego Ducha ${ }^{26}$.

W następnym zaś punkcie czytamy, iż „mając na uwadze ten cel, to znaczy głębsze nawrócenie wszystkich do Boga, dialog międzyreligijny ma swoją własną wartość" ${ }^{27}$. Jego racją jest uniwersalna i aktywna obecność Chrystusa poprzez swojego Ducha w sercach wszystkich ludzi. Tutaj dokonuje się wymiana i dzielenie się, które ,polegają na wspólnym świadectwie

\footnotetext{
${ }^{26}$ Dialog i przepowiadanie, 40.

27 Tamże, 41.
} 
o tym, w co każdy wierzy i na wspólnym odkrywaniu wzajemnych przekonań religijnych" 28 . W dialogu chrześcijanie i wyznawcy innych religii wzywani są do głębszego nawrócenia się do Boga i do pogłębienia swojego zaangażowania się we własną wiarę. Ze strony chrześcijańskiej celem dialogu nie jest nawracanie innych na chrześcijaństwo, lecz wzajemne ubogacenie się i wspólnota ducha z tymi, którzy nie podzielają naszej wiary. Przepowiadanie Ewangelii zmierza do pokazania innym jasnego obrazu Jezusa i tego, czego Bóg dokonał w Nim dla zbawienia świata. W tym celu obecne jest także zaproszenie skierowane do innych, by stali się uczniami Jezusa i weszli do wspólnoty Kościoła, którą On założył.

\section{Wymagania dialogu}

Dialog międzyreligijny stawia jego uczestnikom własne wymagania. Nie może on być ani prawdziwy, ani autentyczny, jeśli nie są one spełnione. Oprócz takich dyspozycji, jak otwartość, życzliwość i zdolność słuchania, partnerzy dialogu muszą posiąść także umiejętność wejścia w religijne doświadczenie drugiego i podjąć wysiłek jego zrozumienia. Nie oznacza to brania swojej wiary w nawias. Przeciwnie, przestrzeganie i szacunek dla tożsamości i integralności własnej wiary jest warunkiem sine qua non czystego i uczciwego dialogu międzyreligijnego. Dialog międzyreligijny nie dopuszcza żadnej formy kompromisu czy redukcji w zakresie podstawowej treści własnej wiary. Każdy uczestnik dialogu

musi być konsekwentny względem własnej tradycji i przekonań religijnych i otwarty na zrozumienie innych, bez obłudy zamykania się w sobie, ale z poczuciem prawdy, pokory, uczciwości, świadomy, że dialog może wzbogacić każdego. Nie może być tu żadnej rezygnacji ani irenizmu, lecz wzajemne świadectwo dla wspólnego postępu na drodze poszukiwań i doświadczeń religijnych, a jednocześnie dla pokonania uprzedzeń, nietolerancji i nieporozumień (RM 56).

Autentyczny dialog międzyreligijny nie dozwala także na żadną formę synkretyzmu czy eklektyzmu. Nie ukrywa ewentualnych sprzeczności między poszczególnymi tradycjami religijnymi, lecz przyjmuje je z cierpliwością. Maskowanie ich pozbawiałoby dialog interreligijny jego własnej celowości.

28 Tamże, 40. 
Chcąc „osiagnacé zamierzony cel - pisze R. Panikkar - dialog między religiami musi być autentycznym spotkaniem międzyreligijnym"29. Z tej podstawowej zasady wynikają szczegółowe normy, którymi powinni się kierować uczestnicy dialogu. Pierwszą z nich, zdaniem R. Panikkara, jest unikanie w międzyreligijnym dialogu wszelkiej apologii, czyli obrony własnej religii, przez „wykazywanie jej prawdziwości i wyższości nad innymi religiami”30. Taka postawa niejednokrotnie rani wyznawców innych religii. Ujawnia bardziej znamiona „krucjaty” przeciwko nim, niż prawdziwego $\mathrm{z}$ nimi dialogu.

Spośród innych norm dialogu, o których mówi R. Panikkar, ważne wydają się te, które przypominają, iż dialog między religiami nie ,jest spotkaniem filozofów” ani „teologów” 31 . Religia bowiem nie jest tylko zbiorem doktryn, lecz przede wszystkim „zaangażowaniem życiowym" ${ }^{32}$. Z istoty swej jest ona żywą relacją z rzeczywistością, którą opisują w swoich pojęciach konkretne doktryny filozoficzne. Podobną rolę jak filozofia pełni w dialogu międzyreligijnym także teologia. Dostarcza koniecznych argumentów do wzajemnego zrozumienia, jednak nie utożsamia się z celem, do którego zmierza spotkanie religijne. Każde spotkanie religijne ,jest spotkaniem w wierze, nadziei i Miłości”33. Jest „aktem religijnym, a więc aktem uświęconym, dzięki któremu idziemy w prawdzie i lojalnie na spotkanie «trzem światom» (trois mondes), bez ubocznych intencji czy celów. Jest to twórczy akt religijny, w którym ujawnia się żywotność religii” ${ }^{34}$.

\section{Formy dialogu}

Postawa Kościoła wobec wyznawców innych religii rozróżnia cztery główne i typowe formy dialogu międzyreligijnego: dialog życia, dialog dzieł i współpracy, dialog wymiany teologicznej i dialog doświadczenia religijne$\mathrm{go}^{35}$. Aczkolwiek nie został w nim określony stopień ważności żadnej z tych form, to jednak sama ich treść i porządek nasuwają pewne refleksje. Zasadniczą rolę przypisuje dokument tej formie dialogu międzyreligijnego, jaką

29 R. Panikkar, Czym jest dialog między religiami?, „Zeszyty Misjologiczne Akademii Teologii Katolickiej” 2 (1979), cz. I, s. 76.

${ }^{30}$ Tamże, s. 76n.

31 Tamże, s. 78n.

32 Tamże.

33 Tamże, s. 80.

34 Tamże, s. 81.

35 Postawa, 28-34; zob. także Dialog i przepowiadanie, 42. 
jest dialog życia. Polega on na kreowaniu w każdym środowisku ewangelicznej atmosfery. Do dialogu życia wezwany jest „każdy wyznawca Chrystusa" ${ }^{36}$. Tutaj, jak zauważa J. Urban, dialog nie jest jakąś teorią, lecz żywą relacją między ludźmi żyjącymi w konkretnym środowisku, którzy wspólnie przeżywają cierpienia, radości, problemy i troski, z jakimi borykają się na co dzieñ $^{37}$. Codzienne obcowanie wyznawców różnych religii ze sobą w duchu szacunku, tolerancji i przyjaźni służy pełniejszemu rozwojowi ich człowieczeństwa. Poprzez świadectwo swojej wiary wzbogacają się oni także o duchowe i nadprzyrodzone wartości ${ }^{38}$.

Na drugim miejscu dokument mówi o dialogu „,w zakresie dzieł i współpracy, podejmowanych na płaszczyźnie humanitarnej, społecznej, ekonomicznej i politycznej, których celem jest wyzwolenie i wyniesienie człowieka" ${ }^{39}$. Członkowie różnych tradycji religijnych, wychodząc $\mathrm{z}$ własnych przekonań, mogą i powinni angażować się wspólnie na rzecz praw człowieka, sprawiedliwości, godności i wyzwolenia człowieka. Służy to przede wszystkim promowaniu świata bardziej ludzkiego, i w ostatecznym wymiarze jest działaniem ,na rzecz zbawienia świata"40.

Dwie pierwsze formy dialogu, dialog życia i dialog dzieł, wydają się być szczególnie ważne w codziennych relacjach między wyznawcami różnych religii. Decydują one o autentyczności wyznawanej przez nich wiary. Dialog życia winien przemieniać się dialog dzieł i współpracy. Dopiero na tym fundamencie może mieć miejsce autentyczny dialog wymiany teologicznej i dialog doświadczenia religijnego.

Dialog wymiany teologicznej, zwany także dialogiem ekspertów ${ }^{41}$, nie jest dostępny dla wszystkich. Zarezerwowany jest jedynie dla specjalistów, którzy „starają się pogłębić zrozumienie wzajemnego dziedzictwa religijnego i docenić wartości duchowe jedni drugich" ${ }^{\text {"42 }}$. Przedmiotem tego dialogu jest szeroko rozumiana problematyka doktrynalna danej religii, przede wszystkim zagadnienie Boga, relacji człowieka do Niego, nauka o zbawieniu, eschatologia. Ma miejsce tutaj tzw. „wnikanie w głąb” doktryny religijnej partnera dialogu, próba uchwycenia jej istoty, przy jednoczesnym zachowaniu wierności dla własnej tradycji religijnej.

36 Postawa, 30.

37 J. Urban, dz. cyt., s. 189.

38 Tamże; zob. także, E. Sakowicz, Dialog, s. 226-230; E. Sakowicz, A. Piwko, Dialog międzyreligijny, „Ateneum Kapłańskie” 153 (2009), z. 3 (604), s. 439n.

39 Postawa, 31.

40 J. Urban, dz. cyt., s. 195.

41 Postawa, 33-34; Dialog i przepowiadanie, 42 c.

42 Tamże. 
$\mathrm{Na}$ ostatnim, czwartym miejscu, dokumenty Kościoła wymieniają dia$\log$ doświadczenia religijnego ${ }^{43}$. „Osoby zakorzenione we własnych tradycjach religijnych" dzielą się tutaj swoimi bogactwami duchowymi, jakimi są na przykład doświadczenie modlitwy i kontemplacji, wiara ,i drogi poszukiwania Boga czy Absolutu" ${ }^{44}$. Dialog doświadczenia religijnego nie jest sesją naukową specjalistów od mistyki i życia duchowego różnych tradycji religijnych, lecz ludzi głęboko wierzących, którzy dzielą się bogactwem darów, jakie otrzymali od Boga ${ }^{45}$. W tym dialogu zasadniczą rolę spełnia modlitwa. Jest ona właściwie pierwszą formą dialogu międzyreligijnego. Rodzi ducha braterstwa i bliskości wyznawców różnych religii w obliczu Boga ${ }^{46}$.

Solidarna obecność na modlitwie, „bycie razem, aby się modlić”, bez zatracenia własnej tożsamości religijnej, miało miejsce na oczach świata 27 października 1986 r. w Asyżu, podczas Światowego Dnia Modlitwy o Pokój. Była to inicjatywa papieża Jana Pawła II, który zaprosił do Asyżu przedstawicieli różnych religii świata, aby w mieście św. Franciszka modlić się o pokój. Myślą przewodnią spotkania było przekonanie papieża o tym, że „wszystkie religie świata, pomimo dzielących je zasadniczo różnic, powołane są do wnoszenia własnego wkładu w dzieło tworzenia bardziej ludzkiego, sprawiedliwego i braterskiego świata" ${ }^{47}$.

Z perspektywy czasu spotkanie w Asyżu było wydarzeniem przełomowym w historii Kościoła. Miało charakter wyłącznie religijny. Odbyło się „pod znakiem modlitwy, postu i pielgrzymowania”, jedynie w tym celu, by prosić Boga „o wielki dar pokoju”48. Pokój rodzi się najpierw w sercu człowieka. Nie jest wynikiem jedynie negocjacji politycznych, kompromisów czy ekonomicznych przetargów. Oprócz tego istnieje jeszcze inny, ważniejszy sposób szerzenia pokoju. Jest nim modlitwa. Z niej i tylko z niej, mówił Jan Paweł II, „może wyłonić się kształt wspólnego działania i świadectwa w sprawie pokoju"49. W słowach wprowadzenia do wspólnej modlitwy chrześcijan przypomniał zgromadzonym: „nasza wiara uczy, że pokój jest darem, który winien wyrażać się w modlitwie kierowanej ku Temu, w któ-

${ }^{43}$ Postawa, 35; Dialog i przepowiadanie, 42 d.
${ }^{44}$ Tamże.
${ }^{45}$ J. Urban, dz. cyt., s. 201.
${ }^{46}$ Tamże, s. 201 r.
${ }_{47}$ Jan Paweł II, , Być razem, aby się modlić” (o zbliżającym się spotkaniu w Asyżu, 22 października 1986), „L'Osservatore Romano” VII (1986), nr 10 (84), s. 7.

48 Tamże, s. 6.

49 Tenże, Naszym wspólnym trudem będzie modlitwa o pokój (Do uczestników konferencji sekretarzy światowych wspólnot chrześcijańskich, 21 października 1986), „L'Osservatore Romano" VII (1986), nr 10 (84), s. 13. 
rego rękach spoczywają losy wszystkich narodów"50. Podczas modlitwy powszechnej, w imieniu całego Kościoła, wyraził ,żal za popełnione błędy, które doprowadziły do naruszenia pokoju, krzywdy innych ludzi, rozdźwięków i niezgody. Błagamy Boga o przebaczenie naszej pychy, zazdrości, fałszywych ambicji i chciwości, które czasem kazały nam zapominać o naszym powołaniu jako tych, którzy mają zaprowadzić pokój" ${ }^{51}$. Podczas spotkania z przedstawicielami religii pozachrześcijańskich po zakończeniu Światowego Dnia Modlitwy o Pokój dnia 31 października 1986 r. w Rzymie, papież wyraził swoje głębokie przekonanie, że inne religie, podobnie jak chrześcijaństwo, uczą również „poszanowania sumienia, miłości bliźniego, sprawiedliwości, przebaczenia, opanowania, oderwania się od stworzeń, modlitwy i medytacji” ${ }^{52}$. Wszystkie te wartości, obecne w wielkich religiach świata, mogą stać się ważnym czynnikiem uśmierzania przemocy i obrony człowieczeństwa oraz fundamentem prawdziwego pokoju.

Wszystkie wielkie religie świata są dzisiaj otwarte na perspektywę dialogu. Jest to znak naszych czasów. Dialog religii monoteistycznych (judaizm, islam i chrześcijaństwo) prowadzony jest już od dawna. Przed dialogiem chrześcijaństwa $z$ religiami Wschodu jest jeszcze długa i daleka droga. Zanim wyłonią się tutaj punkty styczne, „trzeba najpierw oswoić się z różnicami i uczuciem obcości" ${ }^{53}$ w spotkaniu z nimi. Tym, co najbardziej łączy wszystkie wielkie religie świata, to obecne w nich wartości moralne. Ich przypominanie staje się dzisiaj bardziej niż kiedykolwiek aktualne i potrzebne światu, w którym odradzają się nieustannie różnego rodzaju fanatyzmy i skrajne nacjonalizmy. Manipulują one ludzkimi uczuciami religijnymis ${ }^{54}$. Świat, w którym żyjemy, ulega także coraz silniej „presji techniczno-ekonomicznej”. Potrzebne jest również przypominanie prawdy o człowieku; kim jest człowiek, jaka jest jego prawdziwa godność i powołanie. Jest to niezbywalne powołanie wielkich religii świata.

${ }^{50}$ Tenże, Abyśmy nieśli pokój dając wspólne świadectwo (słowa papieża wprowadzające do wspólnej modlitwy chrześcijan, Katedra św. Rufina, Asyż, 27 października 1986), „L'Osservatore Romano" VII (1986), nr 10 (84), s. 16.

${ }^{51}$ Tenże, Modlitwa chrześcijan o pokój (Katedra św. Rufina, Asyż, 27 października 1986), „L'Osservatore Romano” VII (1986), nr 10 (84), s. 14.

${ }_{52}$ Tenże, Religie posiadaja moc kierowania ludzkimi sercami (Do przedstawicieli religii niechrześcijańskich, uczestników Dnia Modlitwy o Pokój, Rzym, 31 października), „L’Osservatore Romano"VII (1986), nr 10 (84), s. 14.

${ }_{53}$ C. Geffré, dz. cyt., s. 2401.

54 Tamże, s. 2402. 


\section{Der interreligiöse Dialog (Zusammenfassung)}

Der Interreligiöse Dialog bedeutet neue Wirklichkeit. Bekenner varschiedener Religionen trafen sich schon immer miteinander. Sicherlich tauschten sie auch ihre Meinungen zu dem von ihnen bekannten Glauben. In der offiziellen Lehre der Kirche fehlte es schon lange an der positiven Äusserung über nichtchristliche Religionen. Der Wendepunkt in der Geschichte ist die Lehre des II. Vatikanischen Konzils.

Diese Arbeit stellt im Umriss die Wirklichkeit des interreligiösen Dialogs in folgenden kirchlichen Unterlagen: Ecclesiam suam, Vaticanum II und nach dem Konzil. Sie bespricht auch gründliche Anforderungen, Ziele und Formen des interreligiösen Dialogs. 